\title{
The Meaning of Human Relations in Existential Philosophy and Its Reflection in Contemporary Art
}

DOI: http://dx.doi.org/10.12775/RF.2018.010

\section{Introduction}

There are philosophies in which human intercourse is regarded as one of the most pleasurable and meaningful phenomena. On the other hand, given conventions and popular life styles induce us to face a risk of relations that were penetratingly named "human all too human" by Friedrich Nietzsche. An importance of the issue was reconsidered in the Heideggerian thought on being-with as a constitutive part of Dasein existence and problems of finding some mode of being-with others such that $D a$ sein is not dissolved in publicness, idle talk, averageness. Nowadays, an analogous issue is interpreted in Zygmunt Bauman's theory of a liquid character of contemporary life and in many more critical investigations of consumerist culture. However, the features of human intercourse are in the centre of philosophical thought on personal existence. So, the aim of our article is to look into the concepts of human relations in most distinctive forms of existentialism, i.e., Jacques Maritain's Christian existentialism, Karl Jaspers and Albert Camus's laic philosophies. Then, we extend our research into the reconsiderations of being together in contemporary branches and practices of art seeking to regain meaningful relations, reinstate confidence in people from different cultures and backgrounds. 


\section{Concept of Human Communication from a Philosophical Perspective}

It is obvious that human intercourse is a many-sided phenomenon and we need to characterize its aspects. Typically, communication is aimed to achieve daily practical and professional purposes and means an exchange of information or civilized but almost idle talk. According to Jaspers, the situation is "that more and more men do not understand one another, that they meet and scatter, that they are indifferent to one another, that there is no longer any reliable community or loyalty" (Jaspers 1964: 25). Human beings deceive themselves in a multitude of friendships based on softness and complaisance; assents occur as a consequence of friendly cooperation, of yielding to persuasion, as nobody wants to engage into true consideration of a matter. The philosopher tells that "not merely an exchange of words, nor friendliness and sociability, but only the constant urge towards total revelation reaches the path of communication" (Jaspers 1960: 146). Naturally, he touches upon love which "binds two human beings together unconditionally for the whole of their future" (Jaspers 2010: 185), mentions friendship through scientific research, communication based on intellectual ideas (Jaspers 1948: 340-342), but most profoundly looks into communication as a meeting of the two selves. This kind of human relation, using his own terms, existential communication is the topic of his lifelong concern.

In the last paragraphs of his book entitled "Philosophical Faith" the author claims that "the main topic of philosophy becomes the elucidation of the communication from its manifold springheads on the ways of encompassing [Umgreifende]" (Jaspers 1948: 136). "Encompassing" is his term coined to describe a particular concept of true being, that encompasses objective and subjective sides of the whole world and includes instants of transcendence at times irradiating it. Thus, the quoted statement means that, according to Jaspers, existential communication is related to the very being and to the philosophical thinking. Personal comprehension of the world causes willingness to express it, to share an experience with others; thus, the philosophy is aimed at communication. On the other hand, communication is a source of philosophical thought, as it supposes taking nothing for granted, doubting, questioning everything, and endless search for truth that are characteristic of an open discussion. As Jaspers puts it, "communication is the path to truth in all its forms" (Jaspers 1960: 148); "communication from understanding to understanding, from mind to mind, and also from existence to existence, is only a medium for impersonal meanings and values" (Jaspers 1964: 25-26). It is worth mentioning that the well-known Jürgen Habermas's theory of communicative action based on the idea that the very content 
of argument does not compile a sufficient condition for an achievement of just impartial decisions, as actually the achievement requires a process of real intercourse, appeared a few decades later than Jaspers' thought which is approached in our consideration. Our author states that without authentic communication a person disorientates in the multiplicity of disparate experience and in a variety of heard opinions. He cannot acquire his true selfhood in isolation or solitary devotion to nature, "whereas to the extent that it is itself, it comes from an other and sees itself in relation to the other" (Jaspers 1971: 42). The philosopher believes that human beings could find the common ground which connects even the opponents. Therefore, they need to remember the rules of conduct in chivalry and obey them when they reflect on viewpoints, decisions, and conclusions. Jaspers proposes loving contests in which the defense and attack cease being means by which people gain power and become means by which they unite with each other in attainment of truth and peace. According to him, "the loving struggle provides all means of forcefulness to the partner in equal proportion as to oneself - including the means of intellectual violence, where stronger rationality equals greater muscle strength - and thus eliminates the lethal effect of violence" (Jaspers 2014: 2-3). Thus, he upholds the view that the very communication might extinguish violent conflicts and that this is its main mission.

Likewise, the search for authentic being, mutual understanding, and true humanity are the topics of Albert Camus's philosophy. We might say that he is even more famous for his critics of human intercourse which is prevalent in usual daily life. As a matter of course, Camus affirms that the life and consequently - all the usual things in it - are inherently absurd and leaves a question of the possibility to defeat absurdity open. On the other hand, he often thinks about human relations when he searches for the modes of making the meaning of life. More than once, the philosopher reflects on human solidarity in his book "The rebel: an essay on Man in revolt"'. He reminds of Prometheus's metaphysical rebellion for human beings (Camus 1958: 26-27), declares that the metaphysical character of human solidarity emerges from the very essence of rebellion, as when a man rebels, he "identifies himself with other men and so surpasses himself" (Camus 1958: 17), sensitively takes notice that "it can often happen that we cannot bear to see offenses done to others which we ourselves have accepted without rebelling" (Camus 1958: 16-17). The community in shielding of humanity and in seeking justice is vividly described in an episode of "The Plague" which tells about the conversation between the main characters - Rieux and Tarrou - and then their swimming in the sea (Camus 1963: 208-210). Perhaps most tellingly Camus evaluates genuine human relations in "The Myth of Sisyphus". As he writes, "there is but one luxury for them - that of human relations. 
How can one fail to realize that in this vulnerable universe everything that is human and solely human assumes a more vivid meaning? Taut faces, threatened fraternity, such strong and chaste friendship among men - these are the true riches because they are transitory" (Camus 1991: 88). These quotes let us point up the emotional aspect of genuine human relations in Camus's thinking. He accentuates human proximity, mutual sympathy, and support in severe circumstances of the essentially godless and meaningless world.

The third theory which is under our consideration seems to share some features of the conceptions we have already discussed. Surely, Jacques Maritain acknowledges the existence of the divine source of meaning in our lives and in an ulterior eternal world. Similarly to Camus's approach to essential emotional aspect of true human relations, Maritain notices that the very word fellowship "conjures up the image of traveling companions, who meet here below by chance and journey through life - however fundamental their differences may be - good humouredly, in cordial solidarity and human agreement..." (Maritain 1957: $21)$. But then he continues, “... or better to say, friendly and cooperative disagreement" (Maritain 1957: 21), as if echoing Jaspers' views. The Christian thinker affirms that there might be some kind of cooperation between philosophers if they are ready to reflect on their own theories by seeing, thanks to another's thought, more profoundly into their own ones. This intercourse should be founded on intellectual justice and on the duty of understanding philosophical ideas in a genuine and fair manner. The true relationship lets people absorb into their minds whatever worlds of other's thought might hold of truth. For Maritain, as for Jaspers, genuine human relations require a particular condition - possibility to transcend our daily world and to reach some heavenly region of the very being. As Maritain puts it, "men really communicate with one another only by passing through being or one of its properties. Only in this way do they escape from the individuality in which matter encloses them. If they remain in the world of their sense needs and of their sentimental egos, in vain do they tell their stories to one another, they do not understand each other. They observe each other without seeing each other, each one of them infinitely alone, even though work or sense pleasures bind them together" (Maritain 1962). Nevertheless, then the philosopher assures that great artists might create works which move our souls to communicate.

\section{Reflection of Human Intercourse in Contemporary Art}

This assurance reminds us that an artwork has always been a means of indirect communication between its creator and beholders. Frequently, works of art of any time let us experience a kind of representation of hu- 
man relations. For instance, Roland Barthes observes that the pleasure of reading a novel might be produced by the representation of the daily life of an epoch of a character, if the reader allays with him, as certain joy arises due to "the 'detail', the tiny private scene, in which I can easily take my place" (Barthes 1998: 53). According to Peter Sloterdijk, the analysis of installations revealed the significance of participation, situatedness, being-connected (Sloterdijk 2013: 255-256). As a yet lesser-known English philosopher Paul Crowther suggests, even music might be approached as an invisible conversation consisting "of different voices or gestures, or different personal situations constantly developing and responding to one another - building into moments of confrontation, resolution, and fulfillment" (Crowther 2015).

Nevertheless, the contemporary art seeks a more immediate intercourse with its audience. Similarly to philosophers, artists reflect on the lack of genuine relationships in the production- and consumption-oriented world. Our situation is figuratively described in a usual phrase which is ironically repeated by the French art curator and critic Nicolas Bourriaud: "You are looking for shared warmth, and the comforting feeling of well being for two? So try our coffee..." (Bourriaud 2002: 9). He asks if it is still possible to create a space of human relationships at least partly protected from our usual behavioral patterns. His conclusion made after the wide-ranging study of contemporary artistic practices seems to be positive. The theorist characterizes the specific nature of a lot of new artworks as a mode of creating human relations which differ from their present-day shapes that are consistently imposed upon people. In Bourriaud's view, "artistic practice is now focused upon the sphere of inter-human relations... artist sets his sights more and more clearly on the relations that his work will create among his public, and on the invention of models of sociability" (Bourriaud 2002: 28).

There are many forms of reflection on alienation, consumerist attitude to others and even oneself in newest art movements. The creation of some artworks is considered as thematization of a lack of human inward and intimate touch (Elsaesser, Hagener 2015: 135-136). Works of Transgressive, Transhumanist, Participatory art, recent Marina Abramović performances might be conceived as an involvement of publics into the silent or direct communication and joint search for new existential experiences, for changes in our understanding of ourselves and of the world around us. Activism artists produce the conditions for the participative creation online, as well as practices based on interpersonal contact. The critics acknowledge interpersonal dimensions of the "international meetings, periods in residency, living together, the exchange of knowledge, discussion forums that establish intervention agendas and strategies, parties and carnivalesque practices, and the dispersion of figures in terms of direction or hierarchy" (Giunta 2013: 241). 
There are art movements especially commissioned to reinstate human confidence, mobilize the community coherence in transforming crisis. A Swiss scientist and musician, Paolo J. Knill stresses the role of community art in resilience of the communal life after the catastrophic events or national conflicts. He argues that the creation of a communal work of art provides the opportunities to engage in activities that the people have not completed with each other before, to overcome habitual restrictions, to communicate "with those with whom normally they may have little contact or shy away from" (Knill 2012: 55). His research makes a part of the artistic development named "Expressive Arts and Social Change", based on the theory that the people have the ability to reshape their worlds creating the alternative imaginable surroundings within the literal reality in which they exist. An interaction in this world of imagination helps the members of conflict-laden groups to see themselves and others in a new way, to restore the reliance in their capacities of living together. According to the co-founder of the expressive arts development, Stephen K. Levine, the experience of making art together gives the possibilities to find new "types of association that aid in reviving the sense of community itself" (Levine 2012: 28).

\section{Conclusion}

The consideration of the meanings of human relations in existential philosophy shows an actuality of its critical approach to prevalent forms of communication in contemporary consumerist societies. Usual communication is an exchange of information aimed to achieve daily utilitarian purposes or is similar to friendly idle talk. Existential philosophers pay a specific attention to the communication among people holding opposite views or different believes. Their attempts to propose some reinstatement of the genuine relations lead to the ideas of approaching communication as a meeting between the two authentic selves and reflecting possibilities to experience the realm which transcends our daily world. Another search for solution can be found in Karl Jaspers' notion of "loving struggle" (or "loving contest") for truth as distinct from an intercourse motivated by struggle for social capital, practical interest or utility. The loving struggle is interpreted as a means to reconstruct meaningful human intercourse even in the cases of violent conflicts between different national and political forces.

In last decades there has been an increase in branches of art which turned human relations into an issue. Being together becomes a subject matter and a medium of its expression in new performances, in a lot of community art, and in relational artworks which are especially devoted to reshaping common communicational patterns. The creation of art is 
seen as a mode to rethink and reconstruct modes of inter-personal contacts, to restore awareness in the meaningfulness of being together.

\section{Bibliography}

Barthes Roland, The Pleasure of the Text, Hill and Wang, New York 1998.

Bourriaud Nicolas, Relational Aesthetics, Les presses du réel, Paris 2002.

Camus Albert, The Rebel: an Essay on "Man in Revolt", Vintage Books, New York 1958.

Camus Albert, The Myth of Sisyphus and other Essays, Vintage Books, New York 1991.

Camus Albert, The Plague, Penguin Books, Harmondsworth 1963.

Crowther Paul, On Why We Need Art - The Aesthetics of Self-Becoming, 2015. Retrieved on 25.05.2017. http://www.academia.edu/13714594/On_Why_ We_Need_Art_-_The_Aesthetics_of_Self-Becoming_

Elsaesser Thomas and Hagener Malte, Film Theory: An Introduction through the Senses, Routledge, New York 2015.

Giunta Andrea, "Activism" in Contemporary art: 1989 to the present, ed. by Alexander Dumbadze and Suzanne Hudson, Wiley-Blackwell, Chichester, Malden (Mass.) 2013, p. 234-244.

Jaspers Karl, Der Philosophische Glaube, R. Piper \& Co., München 1948.

Jaspers Karl, Philosophie, Springer, Berlin 1948.

Jaspers Karl, On my Philosophy, in: Existentialism from Dostoyeusky to Sartre, ed. by Walter Kaufman, Meridian Books, Inc., New York 1960.

Jaspers Karl, Way to Wisdom: An Introduction to Philosophy, Yale University Press, New Haven and London 1964.

Jaspers Karl, Philosophy of Existence, University of Pennsylvania Press, Philadelphia 1971.

Jaspers Karl, Man in the Modern Age, Routledge, Abington, New York 2010.

Jaspers Karl, Truth, Freedom, and Peace, "Existenz: An International Journal in Philosophy, Religion, Politics, and the Arts", Vol. 9, 2014, No. 2, p. 1-12.

Knill Paolo J., Communal Art-making and Conflict Transformation, in: Art in Action. Expressive Arts Therapy and Social Change, eds. Levine Ellen G., Levine Stephen K., Jessica Kingsley Publishers, London and Philadelphia 2012, p. 53-77.

Levine Stephen K., Art Opens to the World: Expressive Arts and Social Action, in: Art in Action. Expressive Arts Therapy and Social Change, eds. Levine Ellen G., Levine Stephen K., Jessica Kingsley Publishers, London and Philadelphia 2012, p. 21-30.

Maritain Jacques, Truth and Human Fellowship, Princeton University Press, Princeton 1957.

Maritain Jacques, Art and Scholasticism, translated by Joseph W. Evans, 1962. Retrieved on 10.05.2017. http://maritain.nd.edu/jmc/etext/art.htm

Sloterdijk Peter, In the World Interior of Capital: for a Philosophical Theory of Globalization, Polity Press, Cambridge 2013. 


\section{Summary}

The features of human intercourse in contemporary consumerist society are at the centre of philosophical thought on personal existence; therefore, the first part of this article deals with the concepts of human relations in most distinctive existentialisms, i.e., Jacques Maritain's Christian existentialism, Karl Jaspers and Albert Camus's laic philosophies. The philosophical thought on alienation, consumerist attitude to others and even oneself is reflected in a lot of contemporary art movements as well. The creation of art is reconsidered as thematization of a lack of human inward and intimate touch, as relationist activity, as an involvement of publics into the communication and joint search for new existential experiences, for changes in our understanding of ourselves and of the world around us (Participatory art, some works of Transgressive art and Transhumanist art). There are art movements especially commissioned to reinstate of confidence, mobilize of coherence in transforming crisis. The engagement in community art practices helps a person to break the continuity of the flow of suspiciousness, hostility, and despair as well as to regain awareness in the meaningfulness of being together.

Keywords: Being-together, communication, loving struggle, community art, relational art, existential experience.

\section{Streszczenie}

\section{Sens relacji międzyludzkich w filozofii egzystencjalnej i jego odzwierciedlenie w sztuce współczesnej}

Myśl filozoficzna dotycząca ludzkiej egzystencji koncentruje się na charakterze stosunków międzyludzkich we współczesnym społeczeństwie konsumpcyjnym. Z tego też powodu pierwsza część niniejszego artykułu dotyczy pojęcia więzi ludzkiej u najwybitniejszych egzystencjalistów, tj. w chrześcijańskim egzystencjalizmie Jacques'a Maritaina oraz w egzystencjalizmie laickim Karla Jaspersa i Alberta Camusa. Także sztuka współczesna poświęca dużo uwagi filozoficznym rozważaniom na temat alienacji, konsumpcyjnemu stosunkowi człowieka do innych, a nawet do samego siebie. Twórczość artystyczna zostaje przeformułowana jako tematyzacja braku ludzkiego wewnętrznego charakteru, jako działanie o charakterze relacyjnym, jako zaangażowanie publiczności w proces komunikacji i wspólnego poszukiwania nowych doświadczeń egzystencjalnych oraz zmian w pojmowaniu nas samych i otaczającego nas świata (sztuka zaangażowana, niektóre dzieła należące do sztuki transgresyjnej i transhumanistycznej). Niektóre z prądów artystycznych stawiają sobie za cel właśnie przywrócenie pewności siebie, zaktywizowanie integralności podczas przezwyciężania kryzysu. Zaangażowanie w praktyki artystyczne społeczności pomaga ludziom przełamać ciągłą podejrzliwość, wrogość i rozpacz, a także przywrócić świadomość sensowności bycia razem $\mathrm{z}$ innymi.

Słowa kluczowe: bycie-z-innymi, komunikacja, miłosne zmagania, sztuka społeczności, sztuka relacyjna, doświadczenie egzystencjalne 